\title{
Proteins of penial mamilliform glands in closely related Littorina species (Mollusca, Caenogastropoda): variability and possible contribution to reproductive isolation
}

\author{
Arseniy Lobov ${ }^{1,2}$, Irina Babkina', Arina Maltseva', \\ Natalia Mikhailova ${ }^{3}$, and Andrey Granovitch ${ }^{1}$ \\ 'Department of Invertebrate Zoology, Faculty of Biology, Saint Petersburg State University, \\ Universitetskaya nab., 7-9, Saint Petersburg, 199034, Russian Federation \\ ${ }^{2}$ Laboratory of Regenerative Biomedicine, Institute of Cytology, Russian Academy of Sciences, \\ Tikhoretskiy pr., 4, Saint Petersburg, 194064, Russian Federation \\ ${ }^{3}$ Cell Technologies Center, Institute of Cytology, Russian Academy of Sciences, Tikhoretskiy \\ pr., 4, Saint Petersburg, 194064, Russian Federation \\ Address correspondence and requests for materials to Arseniy Lobov, \\ arseniylobov@gmail.com
}

Citation: Lobov, A., Babkina, I., Maltseva, A., Mikhailova, N., and Granovitch, A. 2020. Proteins of penial mamilliform glands in closely related Littorina species (Mollusca, Caenogastropoda): variability and possible contribution to reproductive isolation. Bio. Comm. 65(2): 200-212. https://doi. org/10.21638/spbu03.2020.206

Authors' information: Arseniy Lobov, PhD student, Junior Researcher, orcid. org/0000-0002-0930-1171; Irina Babkina, student, orcid.org/0000-0002-0406-7021; Arina Maltseva, PhD, Associate Professor orcid.org/0000-0003-1973-4728; Natalia Mikhailova, Dr. of Sci. in Biology, Leading Researcher, orcid.org/0000-0003-1650-9330; Andrey Granovitch, Dr. of Sci. in Biology, Professor, orcid.org/0000-0002-5203-104X

Manuscript Editor: Pavel Skutschas,

Department of Vertebrate Zoology, Faculty of Biology, Saint Petersburg State University, Saint Petersburg, Russia

Received: November 4, 2019;

Revised: February 3, 2020;

Accepted: February 11, 2020

Copyright: (c) 2020 Lobov et al. This is an open-access article distributed under the terms of the License Agreement with Saint Petersburg State University, which permits to the authors unrestricted distribution, and self-archiving free of charge.

Funding: The research was supported by the Russian Foundation for Basic Research grant number 18-34-00873 (PI Arseniy A. Lobov). The purchase of basic laboratory equipment was financed by the St. Petersburg State University grant number 0.40.491.2017 (PI Andrey I. Granovitch).

Competing interests: The authors have declared that no competing interests exist.

\section{Abstract}

The forces driving reproductive isolation emergence during the process of sympatric speciation are still intensely debated. Mechanisms of gametic isolation (which are known to form rapidly in several models) take the central place in these debates. Nevertheless, the approximative capacity of a few investigated models to other taxa could be questioned, generating demand for the adoption of additional model organisms to study sympatric speciation. The group of closely related species of the genus Littorina (subgenus Neritrema) sympatrically inhabiting seashores are promising. In this study, we performed comparative proteomic analysis of penial tissues of four Neritrema species to identify potential effectors contributing to gametic isolation. Among 272 analyzed proteins, 13 mamilliform gland-specific proteins (possibly transferred to the female during copulation) were detected, as well as five proteins specifically expressed in the epithelium of the penial basal part. Eight of these proteins were speciesspecific and may be involved in the maintenance of reproductive barriers.

Keywords: Littorina, proteomics, gamete recognition proteins, mamilliform gland, reproductive isolation, gametic isolation, Mollusca, 2D-DIGE.

\section{Introduction}

Reproductive isolation is regarded as a key species criterion within the biological species concept (De Queiroz, 2007). When reproductive barriers emerge without geographic separation, subpopulations appear under the sympatric (as opposed to allopatric) speciation model (Bolnick and Fitzpatrick, 2007; Butlin et al., 2008). Although the mechanisms of sympatric speciation have been actively investigated in the last 30 years, they remain vague in many aspects. One of the possible mechanisms is post-copulatory prezygotic reproductive (gametic) isolation due to incompatibility of molecules involved in fertilization (Swanson and Vacquier, 2002; Matute, 2010; Lobov et al., 2019).

There are few model systems to study gametic isolation, mainly in species of animals with external fertilization (Wilburn and Swanson, 2016). Model organisms with internal fertilization have until recently included only insects and mammals (Vieira and Miller, 2006; Wilburn and Swanson, 2016). A group of cryptic species of genus Littorina (Mollusca, Caenogastropoda) is a newly elaborated model system to analyze gametes incompatibility among internal fertilizers. The subgenus Neritrema comprises two groups of closely related species: "saxatilis" (L. saxatilis (Olivi 1792), 
L.arcana Hannaford Ellis 1978, L.compressa Jeffreys 1865 ) and "obtusata" (L.obtusata (Linnaeus 1758), L.fabalis (Turton 1825)); all of these sympatrically inhabit the European North Atlantic sea shores (Yashenko and Granovitch, 2002; Granovitch et al., 2004). Physiological consequences of local ecological and evolutionary adaptation can be traced in particular species and subpopulations of these molluscs (Sokolova et al., 2000, 2001; Panova and Johannesson, 2004; Rolán-Alvarez et al., 2015; Maltseva et al., 2016). This suggests the importance of ecological sympatric speciation in the evolutionary history of this species group (Johannesson, 2003; Grahame et al., 2006; Rolán-Alvarez et al., 2007, 2015).

All representatives of Neritrema demonstrate a species-specific pattern of mating, but there is evidence that L. saxatilis/L.arcana and L.obtusata/L.fabalis may hybridize in nature (Mikhailova et al., 2009; Granovitch et al., 2013; Costa et al., 2020), and that interspecies copulations occur commonly in L.saxatilis/L.arcana (Mikhailova et al., 2008; unpublished data). Such a case of incomplete reproductive isolation along with certain features of Neritrema periwinkles (e.g., polyandry, sympatry, reinforcement and sexual conflict) serve as preconditions for gametic isolation between the species (Zigler et al., 2005; Kvarnemo and Simmons, 2013; Lobov et al., 2019). Thus, postcopulatory prezygotic reproductive barriers may be expected to contribute to the maintenance of species identities in this species group in sympatry.

In 2013 we launched the project devoted to the analysis of gamete interaction proteins involved in gametic isolation between Littorina species. We assumed that such proteins may have three possible origins in a male (Supplement, SM 1): testis and seminal vesicles (mature eu- and paraspermatozoa), prostate gland (seminal fluid) and penial mamilliform glands. We have characterized the species-specific paraspermal protein LOSP (Lobov et al., 2015, 2018); the analysis of prostate proteomes is in progress; and here we describe the results of interspecies proteomic comparison of mamilliform penial glands secretions.

The precise function of penial glands is unknown; it was suggested that they anchor the penis within the bursa copulatrix during copulation (Buckland-Nicks and Worthen, 1992). Each penial gland consists of four types of secretory cells: cells of multicellular gland (MGC), apocrine secretion cells and two types of mucous cells (Buckland-Nicks and Worthen, 1992; Ganzha et al., 2006). MGCs have extensive rough endoplasmic reticulum, so most likely these cells produce protein secretions. Hypothetically, these secretions may contribute to sperm conditioning and affect sperm viability, and thus could be involved in reproductive isolation. To test this assumption we aim to identify some speciesspecific mamilliform gland proteins. Using a gel-based proteomic approach followed by mass-spectrometric analysis, we compared proteomes of mamilliform glands and basal fragments of penis from L. saxatilis, L. arcana, L. obtusata and L. fabalis.

\section{Material and Methods}

Samples Males of L.saxatilis, L.arcana, L.obtusata and L. fabalis were collected from the sympatric Norwegian populations $\left(70^{\circ} 17^{\prime} 00.0^{\prime \prime} \mathrm{N} 30^{\circ} 58^{\prime} 40.9^{\prime \prime} \mathrm{E}\right)$. The procedure of species identification was described before (Granovitch et al., 2008). Penises were dissected and divided into two parts: mamilliform glands and basal fragments (SM 1). Each piece of tissue was collected into lysis buffer and homogenized (Maltseva et al., 2016).

2D DIGE Samples were conjugated with Cy2, Cy3 or Cy5 fluorophores (Luminoprobe). Three samples were separated in one gel. There were two biological replicates with at least two technical replicates including Cy-fluorophore-swap for each sample. Isoelectric focusing was carried out with IPG ReadyStrip $(18 \mathrm{~cm}$ or $7 \mathrm{~cm}$, pH 3-10, Bio-Rad) in a Protean IEF Cell (Bio-Rad) following the manufacturer's recommendations. The second direction of electrophoresis was performed in $15 \%$ PAAG with a tris/glycine/SDS buffer system (BioRad; Laemmli, 1970). Electrophoregrams were visualized using Typhoon FLA 9500 (GE Healthcare).

Statistical analysis Spot identification for 2D electrophoresis analysis was done in PDQuest (BioRad) software. The final dataset was analyzed in R ( $\mathrm{R}$ Core Team, 2019; Maltseva et al., 2016).

LC-MS/MS Differentially expressed proteins were excised from the Coomassie stained gels and identified by HPLC-tandem-mass-spectrometry (Agilent 6538, Agilent Technologies) following the "bottom up" approach as described earlier (Maltseva et al., 2016). MS/ MS search was done using Agilent Spectrum Mill MS Proteomics Workbench (Agilent Technologies; Rev B.04.00.127) against the L.obtusata (Marques et al., 2019), L. fabalis (Marques et al., 2019), L. saxatilis (Marie Westram et al., 2018), L. littorea (Gorbushin, 2018) transcriptomes and theTrEMBL database for Mollusca [6447] database (2019; 396079 proteins; https:// www.uniprot.org/uniprot/?query=taxonomy: $6447 \% 20$ reviewed:no).

All the technical details of the analysis are present in Supplement 2 (SM 2).

\section{Results and Discussion}

Among 272 protein spots analyzed, the majority were shared among all species and tissues, but there were several species- and tissue-specific proteins (Fig. 1, a-b; SM 3). 

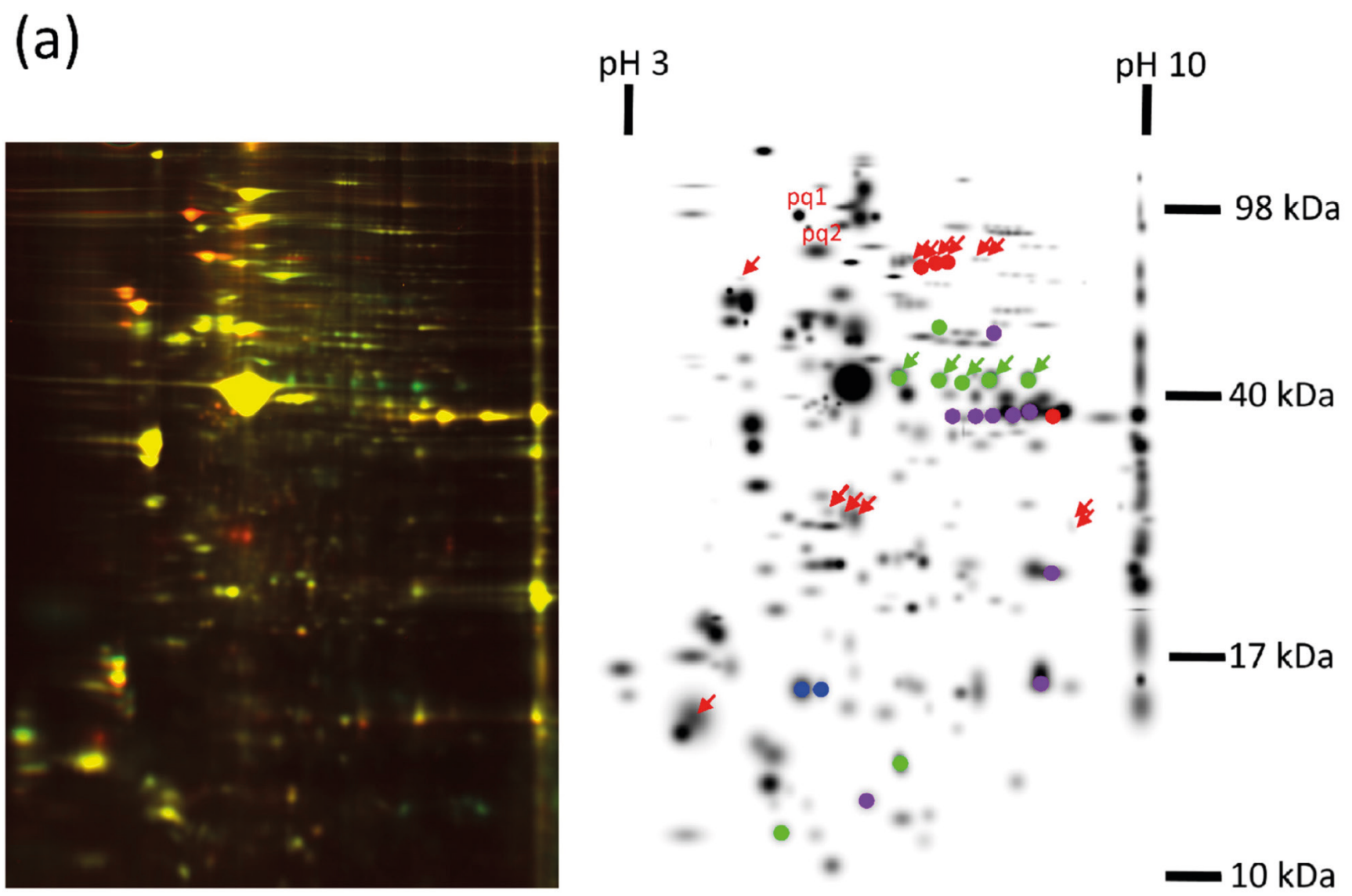

(b)

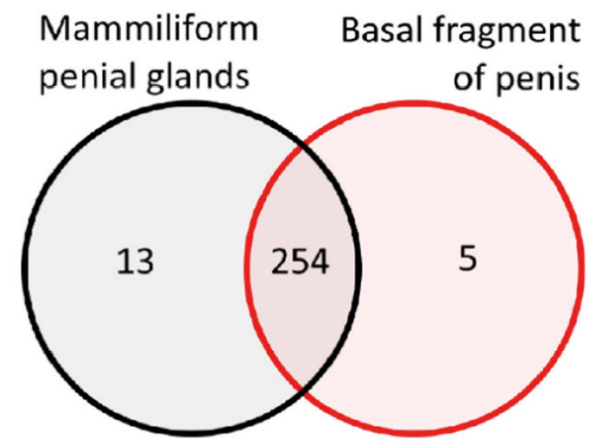

Fig. 1. Penial proteomes of Littorina species. (a) Left - example of 2D-DIGE electrophoregram of mamilliform gland (red) and basal part of penis (green) of L. saxatilis in two merged channels; Right - master gel based on all analyzed 2D-electrophoregrams; Arrows - tissues-specific proteins: red - mamilliform gland specific proteins, green — proteins from the basal part of penis named f_1-f_5; Dots - species-specific proteins: green - L. saxatilis/L. arcana, red - L. obtusata, blue - L. fabalis, purple - L. obtusata/L. fabalis; pq1 and pq2 - proteins with higher abundance in mamilliform gland. (b) - Venn diagram with the numbers of tissue-specific proteins.

\section{Tissue-specific proteins}

There were 13 mamilliform gland-specific and five basal penial fragment-specific proteins (Fig. 1). Although our MS-data were of fine quality in terms of spectra number and intensity, we did not succeed in identifying these tissue-specific proteins. We also found several proteins much more abundant in mamilliform gland samples (pq1 and pq2) and identified only one of them (Fig. 1): pq1 as endoplasmin (Hsp90b1) based on the TrEMBL database. Identification of pq1 protein had maximal score when searched against the TrEMBL database. If available databases for the Littorina species were used, pq1 was still identified as Hsp90b1 (SM 3).

Hsp90b1 is a chaperone functioning as a folding protein in the endoplasmic reticulum (ER) (Chen et al., 2005). Hsp90b1 has been proven to be a rather conservative component of cellular secretory machinery. This fact corresponds well with its predominant presence in mamilliform glands samples (Buckland-Nicks and 
Worthen, 1992). In agreement with its evolutionary conservativeness, no interspecies variability was revealed.

The most probable reason for our failure to identify other proteins is the absence of reproductive proteins in the available databases (Lobov et al., 2015).

\section{Species-specific proteins}

Three mamilliform gland-specific proteins were speciesspecific for L.obtusata (Fig. 1; SM 4). They have similar MW and pI, and probably represent different isoforms of the same protein. Their function is unknown, and does not necessarily have to be "house-keeping" (like pq1 and pq2). It is still plausible that at least some of the mamilliform gland-specific proteins are secreted during copulation and perform some reproduction-specific functions.

Among other species-specific proteins detected here, many were described earlier as proteins expressed in tissues other than penis. However, basal fragmentspecific proteins f_1-f_5 (Fig. 1, a - green arrows with dots; SM 4) were previously detected as both speciesand penis-specific (in comparison to other body parts); mamilliform glands were proposed as the site of their production (Maltseva et al., 2016). Here we confirmed the specificity of $\mathrm{f} \_1-\mathrm{f} \_5$ for the L. saxatilis and L.arcana species pair, but disproved their origin from mamilliform glands; instead, they are expressed in the basal part of the penis. Most probably, their production is related to small glands (each composed of two to three cells) in the epithelium of the penial basal part plus filament and/ or penial sperm groove (Ganzha et al., 2006). If this is the case, they might be involved in sperm conditioning after insemination or penis anchoring during copulation. The first guess implies their possible involvement in gamete recognition and, subsequently, in reproductive isolation between the "L. saxatilis + L. arcana" pair and other species.

\section{Conclusion}

We conducted proteomic analysis of mamilliform penial glands and basal fragments of the penis in four species of genus Littorina. Among 272 analyzed proteins, 13 penial gland-specific proteins may be involved in the secretion process or may be secreted by reproductionrelated tissues; 5 proteins are specifically expressed in the penial basal part. Three mamilliform gland-specific proteins were species-specific for L.obtusata, while all five basal part-specific proteins (probably produced on penial and/or sperm groove epithelium) were specific for L. saxatilis/L.arcana. Based on their localization and species-specificity, these eight proteins may contribute to reproductive barriers, but we have no confirmation yet. In this context, analysis of prostate proteins (components of seminal fluid), which is currently in progress, seems most prospective for disentangling mechanisms of postcopulative reproductive barriers in these periwinkles.

\section{Acknowledgements}

Our research was performed with the technical support of the Resource Centres "Molecular and Cell Technologies" and "Observatory of environmental safety". We thank BioRad for the technical support in proteomic studies.

\section{References}

Avila, F. W., Sánchez-López, J. A., McGlaughon, J. L., Raman, S., Wolfner, M. F., and Heifetz, Y. 2016. Nature and functions of glands and ducts in the Drosophila reproductive tract. In Extracellular Composite Matrices in Arthropods (pp. 411-444). Springer, Cham. https://doi.org/10.1007/9783-319-40740-1_11

Avila, F. W., Sirot, L. K., LaFlamme, B. A., Rubinstein, C. D., and Wolfner, M. F. 2011. Insect seminal fluid proteins: identification and function. Annual review of entomology 56:21-40. https://doi.org/10.1146/annurev-ento-120709-144823

Bingham, F. O. 1972. Several aspects of the reproductive biology of Littorina irrorata (Gastropoda). The Nautilus 86(1):8-10.

Bolnick, D. I. and Fitzpatrick, B. M. 2007. Sympatric speciation: models and empirical evidence. Annual Review of Ecology, Evolution, and Systematics 38:459-487. https://doi. org/10.1146/annurev.ecolsys.38.091206.095804

Buckland-Nicks, J. A. and Worthen, G. T. 1992. Functional morphology of the mammiliform penial glands of Littorina saxatilis (Gastropoda). Zoomorphology 112(4):217-225. https://doi.org/10.1007/BF01632819

Butlin, R. K., Galindo, J., and Grahame, J. W. 2008. Sympatric, parapatric or allopatric: the most important way to classify speciation? Philosophical Transactions of the Royal Society B: Biological Sciences 363(1506):2997-3007. https:// doi.org/10.1098/rstb.2008.0076

Chen, B., Piel, W. H., Gui, L., Bruford, E., and Monteiro, A. 2005. The HSP90 family of genes in the human genome: insights into their divergence and evolution. Genomics 86(6):627-637. https://doi.org/10.1016/j.ygeno.2005.08.012

Costa, D., Sotelo, G., Kaliontzopoulou, A., Carvalho, J., Butlin, R., Hollander, J., and Faria, R. 2020. Hybridization patterns between two marine snails, Littorina fabalis and $L$. obtusata. Ecology and evolution 10(3):1158-1179. https:// doi.org/10.1002/ece3.5943

De Queiroz, K. 2007. Species concepts and species delimitation. Systematic biology 56(6):879-886. https://doi. org/10.1080/10635150701701083

Ganzha, E. V., Granovitch, A. I., Petrova, Y.A., and Mikhailova, N. A. 2006. Analysis of histological structural features of the penial glands of mollusks of the genus Littorina of the North Atlantic. Vestnik Sankt-Peterburgskogo Universiteta. Seriya 3: Biologiya 3(4):40-46. (In Russian)

Gorbushin, A. M. 2018. Immune repertoire in the transcriptome of Littorina littorea reveals new trends in lophotrochozoan proto-complement evolution. Developmental and Comparative Immunology 84:250-263. https://doi. org/10.1016/j.dci.2018.02.018

Grahame, J.W., Wilding, C.S., and Butlin, R. K. 2006. Adaptation to a steep environmental gradient and an associated barrier to gene exchange in Littorina saxatilis. Evolution 60(2):268-278. https://doi. org/10.1111/j.0014-3820.2006.tb01105.x 
Johannesson, K. 2003. Evolution in Littorina: ecology matters. Journal of Sea Research 49(2):107-117. https://doi. org/10.1002/mrd.20542

Kvarnemo, C. and Simmons, L. W. 2013. Polyandry as a mediator of sexual selection before and after mating. Philosophical Transactions of the Royal Society B: Biological Sciences 368(1613):20120042. https://doi.org/10.1098/ rstb.2012.0042

Laemmli, U.K. 1970. Cleavage of structural proteins during the assembly of the head of bacteriophage T4. Nature 227(5259):680. https://doi.org/10.1038/227680a0

Linke, O. 1933. Morphologie und Physiologie des Genitalapparates der Nordseelittorinen. Lipsius und Tischer.

Lobov, A.A., Maltseva, A.L., Mikhailova, N.A., and Granovitch, A. I. 2015. LOSP: a newly identified sperm protein from Littorina obtusata. Journal of Molluscan Studies 81(4):512-515. https://doi.org/10.1093/mollus/eyv010

Lobov, A. A., Maltseva, A. L., Starunov, V. V., Babkina, I. Y., Ivanov, V. A., Mikhailova, N. A., and Granovitch, A. I. 2018. LOSP: A putative marker of parasperm lineage in male reproductive system of the prosobranch mollusk Littorina obtusata. Journal of Experimental Zoology Part B: Molecular and Developmental Evolution 330(4):193-201. https://doi.org/10.1002/jez.b.22803

Lobov, A.A., Maltseva, A. L., Mikhailova, N.A., and Granovitch, A. I. 2019. The molecular mechanisms of gametic incompatibility in invertebrates. Acta naturae 11(3):4-15. https://doi.org/10.32607/20758251-2019-11-3-4-15

Maltseva, A. L., Varfolomeeva, M. A., Lobov, A. A., Mikhailova, N. A., Renaud, P. E., Grishankov, A. V., Volovik K. Y., and Granovitch, A. I. 2016. Measuring physiological similarity of closely related littorinid species: a proteomic insight. Marine Ecology Progress Series 552:177-193. https://doi.org/10.3354/meps11770

Maltseva, A. L., Varfolomeeva, M.A., Lobov, A.A., Starunov, V.V., and Granovitch, A.I. 2019. Handbook "Proteomics and biodiversity: applications, methods, data analysis". KMK Scientific Press. 163 p. (In Russian)

Marques, J. P., Sotelo, G., DaSilva, J. G., Chaube, P., Costa, D., Afonso, S., ... and Macieira de Faria, R. 2019. Littorina fabalis curated transcriptome assembly (based on data from four individuals) (Version 1). Figshare. https://doi. org/10.6084/m9.figshare.9273566.v1

Marques, J. P., Sotelo, G., DaSilva, J. G., Chaube, P., Costa, D., Afonso, S., ... and Macieira de Faria, R. 2019. Littorina obtusata curated transcriptome assembly (based on data from four individuals) (Version 1). Figshare. https://doi. org/10.6084/m9.figshare.9273578.v1

Matute, D. R. 2010. Reinforcement of gametic isolation in Drosophila. PLoS Biology 8(3):e1000341. https://doi. org/10.1371/journal.pbio.1000341

Mikhailova, N. A., Yu, A. G., and Granovitch, A. I. 2008. Analysis of the interspecific crosses frequency in copulating pairs of Littorina marine gastropods of "saxatilis" complex. Vestnik Sankt-Peterburgskogo Universiteta. Seriya 3: Biologiya 3(4):5-9. (In Russian)

Mikhailova, N. A., Gracheva, Y.A., Backeljau, T., and Granovitch, A. I. 2009. A potential species-specific molecular marker suggests interspecific hybridization between sibling species Littorina arcana and L. saxatilis (Mollus- ca, Caenogastropoda) in natural populations. Genetica 137(3):333. https://doi.org/10.1007/s10709-009-9397-4

Panova, M. and Johannesson, K. 2004. Microscale variation in Aat (aspartate aminotransferase) is supported by activity differences between upper and lower shore allozymes of Littorina saxatilis. Marine Biology 144(6):11571164. https://doi.org/10.1007/s00227-003-1274-6

R Core Team 2019. R: A language and environment for statistical computing. R Foundation for Statistical Computing, Vienna, Austria.

Reid, D. G. 1989. The comparative morphology, phylogeny and evolution of the gastropod family Littorinidae. Philosophical Transactions of the Royal Society of London B, Biological Sciences 324(1220):1-110. https://doi. org/10.1098/rstb.1989.0040

Rolan-Alvarez, E., Austin, C., and Boulding, E. G. 2015. The contribution of the genus Littorina to the field of evolutionary ecology. Oceanography and Marine Biology: an annual review 53:157-214. https://doi.org/10.1201/b18733

Saad, L. O., Schwaha, T., Handschuh, S., Wanninger, A., and Marian, J. E. 2018. A mating plug in a squid? Sneaker spermatophores can block the female sperm-storage organ in Doryteuthis plei. Zoology 130:47-56. https://doi. org/10.1016/j.zool.2018.08.002

Sokolova, I. M. and Pörtner, H. O. 2001. Physiological adaptations to high intertidal life involve improved water conservation abilities and metabolic rate depression in Littorina saxatilis. Marine Ecology Progress Series 224:171-186. https://doi.org/10.3354/meps224171

Sokolova, I. M., Granovitch, A. I., Berger, V.J., and Johannesson, K. 2000. Intraspecific physiological variability of the gastropod Littorina saxatilis related to the vertical shore gradient in the White and North Seas. Marine Biology 137(2):297-308. https://doi.org/10.1007/s002270000343

Sutter, A. 2016. Copulatory plugs, In: Weekes-Shackelford, V., Shackelford, T., and Weekes-Shackelford, V. (eds) Encyclopedia of Evolutionary Psychological Science. Springer, Cham. https://doi.org/10.1007/978-3-319-16999-6_69-1

Swanson, W.J. and Vacquier, V.D. 2002. The rapid evolution of reproductive proteins. Nature reviews genetics 3(2):137. https://doi.org/10.1038/nrg733

Vieira, A. and Miller, D. J. 2006. Gamete interaction: Is it species-specific? Molecular Reproduction and Development 73(11):1422-1429. https://doi.org/10.1002/mrd.20542

Westram, A. M., Rafajlovic, M., Chaube, P., Faria, R., Larsson, T., Panova, M., ... Butlin, R. 2018. Littorina saxatilis genome assembly (Version 1). Dryad. https://doi.org/10.5061/ dryad.bp25b65/4

Wilburn, D. B. and Swanson, W. J. 2016. From molecules to mating: Rapid evolution and biochemical studies of reproductive proteins. Journal of Proteomics 135:12-25. https://doi.org/10.1016/j.jprot.2015.06.007

Zhang, Y., Fonslow, B. R., Shan, B., Baek, M. C., and Yates III, J. R. 2013. Protein analysis by shotgun/bottom-up proteomics. Chemical reviews 113(4):2343-2394. https://doi. org/10.1021/cr3003533

Zigler, K. S., McCartney, M. A., Levitan, D. R., and Lessios, H. A. 2005. Sea urchin bindin divergence predicts gamete compatibility. Evolution 59(11):2399-2404. https://doi. org/10.1111/j.0014-3820.2005.tb00949.x 


\section{SUPPLEMENTS}

\section{SM 1 - Scheme of Littorina male's anatomy; indicates tissues assumed to produce gamete recognition proteins}

Testis (yellow) - the tissue where eu- and parasperms are formed; seminal vesicle (green) - the channel were eu- and parasperms are stored before insemination; prostate (pink) - the tissue were seminal fluid proteins undergo synthesis, maturation and exocytosis; mamilliform glands (blue) - specialized glands of unknown function on the penis; basal fragment of penis - the part used as a sample of comparison for identification of mamilliform gland-specific proteins; red dotted line - the border of penis dissection during sample preparation.

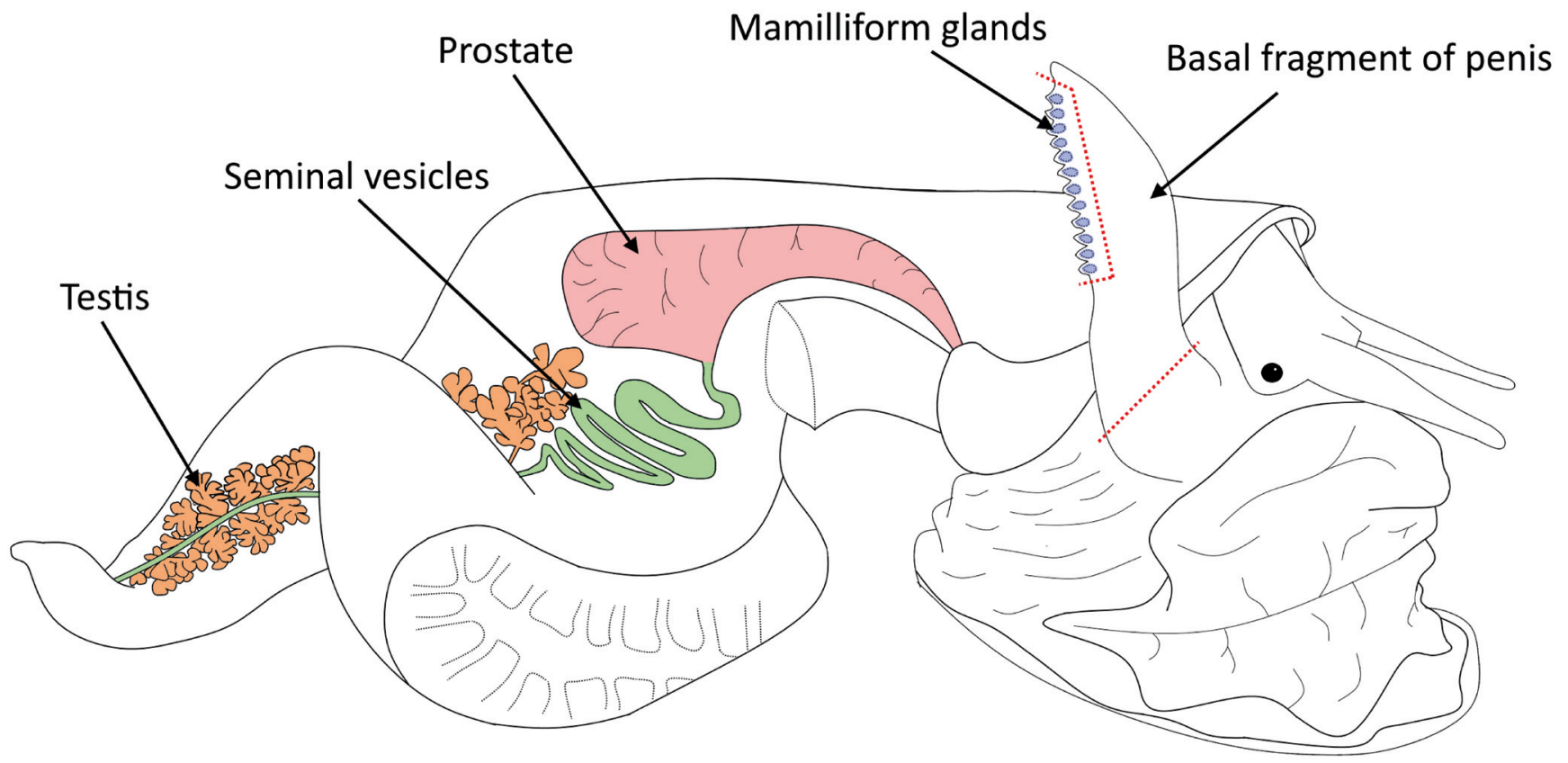




\section{SM 2 - Electrophoresis and protein identification procedures}

In total, 16 different samples of four species (L.saxatilis, L. arcana, L. fabalis, L. obtusata) representing two different parts of a penis (mamilliform glands or basal fragment of a penis) in two biological replicates were subjected to gelbased proteomic analysis. Every samples was a "pooled one", means contained biological material of six individuals, to increase its biological representativeness.

The body parts were put to the lysis buffer (7M Urea, 2M Thiourea, $4 \%$ CHAPS, $30 \mathrm{mM}$ Tris $\mathrm{pH}$ 8,0), frozen in liquid nitrogen, and then homogenized by RETSCH Mixer Mill MM 400 for $20 \mathrm{~min}$ at $30 \mathrm{~Hz}$. Prior to 2DDIGE electrophoresis every sample was analyzed in $1 \mathrm{D}$ electrophoresis for quality control and protein concentration estimation.

Each sample was analyzed in 2D-DIGE at least twice being conjugated with different fluorophores and in combination with different counter samples for comparison. Repeated runs of the same sample were considered as technical replicates $(n=2-4)$. Prior to electrophoretic separation, proteins of each sample were conjugated with the fluorophores Cy2, Cy3 or Cy5 (Luminoprobe, BioDye) in a proportion of $400 \mathrm{pmol}$ of Cy per $50 \mu \mathrm{g}$ of total protein. Samples mixed with Cy-flourophores were incubated for $45 \mathrm{~min}$ on ice in the dark, the reaction was then stopped by the addition of $10 \mu \mathrm{mol}$ of L-lysin, and the samples were further incubated for $30 \mathrm{~min}$ under the same conditions.

The samples conjugated with the different Cy-flourophores were pooled and loaded into an IPG ReadyStrip (18 cm for first biological replicate or $7 \mathrm{~cm}$ for second one, pH 3-10, BioRad) during passive rehydration (overnight at room temperature, in the dark). Separation in the first direction was carried out in the Protean IEF Cell (BioRad) using the method recommended by the manufacturer. Before separation in the second direction, IPG-strips with focused proteins were incubated in equilibration buffers (6 M urea, 2\% SDS, $20 \%$ glycerin, $0.375 \mathrm{M}$ tris, $\mathrm{pH} 8.8$ ) for 15 min: first with $2 \%$ dithiothreitol and then with $2.5 \%$ iodoacetamide. Electrophoretic separation in the second direction was performed in the Protean xii cell (BioRad) for $18 \mathrm{~cm}$ IPG-strips or MiniProtean TetraCell (BioRad) for $7 \mathrm{~cm}$ IPG-strips in 15\% PAAG in Tris/glycine/SDS buffer. The GE Typhoon 9500 FLA laser scanner (GE Healthcare) was used for visualization. Merging of the electrophoregrams was done using ImageJ $1.48 \mathrm{v}$ (http://imagej.nih.gov/ij). For spots excision gels were stained by Coomassie Brilliant Blue G-250 (Amresco).

Protein identification was done in accordance to a 'bottom up' approach, which means tandem mass spectrometry (MS/MS) identification of tryptic peptides by database search. Spots of interest were excised from the gel with a scalpel and cut into pieces. Gel pieces of each spot were destained with $50 \%$ acetonitrile in $25 \mathrm{mM}$ Tris ( $\mathrm{pH}$ 8.2), dehydrated in $100 \%$ acetonitrile and rehydrated in bovine trypsin solution ( $20 \mathrm{ng} \mu \mathrm{l}-1,25 \mathrm{mM}$ Tris, $\mathrm{pH}$ 8.2) on ice for $60 \mathrm{~min}$. After rehydration, any excessive trypsin solution was removed, and gel pieces were covered with $25 \mathrm{mM}$ Tris ( $\mathrm{pH} 8.2$ ) and incubated at $37^{\circ} \mathrm{C}$ overnight. Tryptic peptides were eluted with $50 \%$ ACN/ $0.1 \%$ FA, dried in vacuum concentrator CentriVap (Labconco) and dissolved in $10 \mu \mathrm{l}$ of $5 \%$ ACN/0.1 FA.

The samples were analyzed using liquid chromatography (LC; Agilent 1260) coupled with MS/MS (ESIQ-ToF UHD 6538, Agilent Technologies). The gradient elution method was $10 \% \mathrm{~B}$ to $60 \% \mathrm{~B}$ for $40 \mathrm{~min}$ and further to $100 \% \mathrm{~B}$ (with corresponding decreasing of $\mathrm{A}$ ) for $10 \mathrm{~min}$, where B was $90 \%$ acetonitrile with $0.1 \%$ formic acid, A was $5 \%$ acetonitrile with $0.1 \%$ formic acid, and flow rate was $15 \mu \mathrm{lmin}-1$. We used a Zorbax SBC18 column ( $5 \mu \mathrm{m}$ grain, $80 \AA ̊$ pores, $150 \times 0.5 \mathrm{~mm}$; Agilent Technologies). An MS/MS search was carried out in the mode 'Identity' using Agilent Technologies Spectrum Mill MS Proteomics Workbench Rev B. 04.00.127 software against free databases: L.obtusata (Marques et al., 2019), L. fabalis (Marques et al., 2019), L. saxatilis (Marie Westram et al., 2018), L. littorea (Gorbushin, 2018) transcriptomes and theTrEMBL database for Mollusca [6447] database (2019; 396079 proteins; https://www.uniprot. org/uniprot/?query=taxonomy:6447\%20 reviewed:no); the precursor mass tolerance was set to $\pm 20 \mathrm{ppm}$.

The validation procedure of identified proteins was performed with a minimum two unique peptides and a peptide false discovery rate (FDR) for validated proteins of $1 \%$.

Qualitative and quantitative (was not presented in the article due to low informative value) gel analyses were carried out using PDQuest Advanced 8.0.1 software (BioRad). Normalization for the spot intensity estimates was done by total gel density. Spots with intensity values below the detection limit (i.e. not exceeding 0 relative to the background) were considered as absent for qualitative analysis. Spots were considered as reliably detected if they were detected in at least 2 technical replicates of the same sample, or in 1 technical replicate in at least 2 different samples. We classified potential post-translational modifications and/or splice variants as independent spot signals, because every particular modification and/or splice form possesses its own features and functions. In some cases, we know that these independent spot signals represent different forms of the same enzyme (like arginine-kinase or aldolase, see Maltseva et al., 2016), while in others, it might be suspected owing to similar molecular weight and subtle differences in isoelectric point. 


\section{SM 3 - results of tryptic peptides MS/MS identification of pq1 and pq2}

Despite rapid development of protein and peptide mass-spectrometry, de novo protein sequencing is still challenging. In routine laboratory practice, «bottom-up» analysis is the main approach for mass-spectrometry based protein identification (more information about «bottom-up» protein identification can be found elsewhere, e.g. in Zhang et al., 2013; in Maltseva et al., 2019 (in Russian), etc.).

The first step of this design is proteolysis (usually trypsinolysis). Depending on a sample, it can be the proteolysis of total protein extracts for LC-based proteomics or of just single protein spots after 2D-electrophoresis (as in this research). Then the tryptic peptides are analyzed using tandem mass-spectrometry with inclusion of peptide fragmentation process. Due to stochastic nature of fragmentation, the series of fragment are formed and analyzed to establish original peptide sequence. The peptide identification goes through comparison of obtained spectra with those predicted based on sequences from databases.

Following this strategy, we succeed in identification of only one penial-specific protein: pq1 (see the main text). Here are some details of the protein identification.

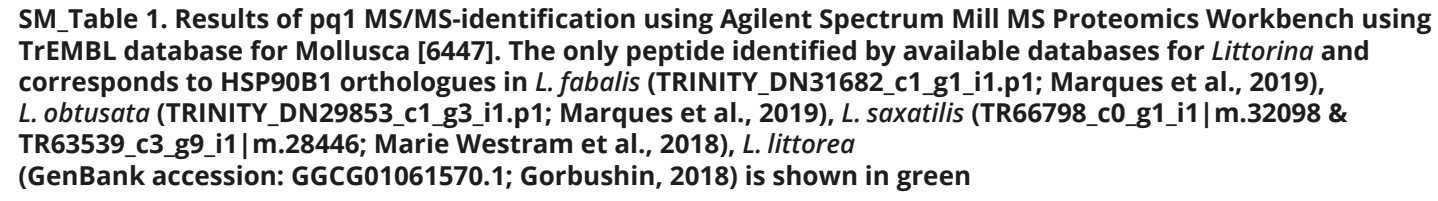

\begin{tabular}{c|c|c|c|c|c|c|c|c}
\hline Name & $\begin{array}{c}\text { Accession } \\
\text { number }\end{array}$ & Species & $\begin{array}{c}\text { Protein MW } \\
(\mathrm{Da})\end{array}$ & Score & $\begin{array}{c}\text { Unique } \\
\text { peptides }\end{array}$ & $\begin{array}{c}\text { \% AA } \\
\text { coverage }\end{array}$ & $\begin{array}{c}\text { Total spectral } \\
\text { intensity }\end{array}$ & $\begin{array}{c}\text { Number of } \\
\text { spectra }\end{array}$ \\
\hline Endoplasmin & A0A210PZR8 & $\begin{array}{c}\text { Mizuhopecten } \\
\text { yessoensis } \\
\text { (Yesso scallop) }\end{array}$ & 91323.1 & 70.76 & 9 & 5.2 & $2.26 \mathrm{e}+006$ & 22 \\
\hline
\end{tabular}

Table of identified unique peptide for pq1

\begin{tabular}{l|l|c|c|l}
\hline \multicolumn{1}{r|}{ Peptide sequence } & \multicolumn{1}{c|}{ Peptide MW (Da) } & $\begin{array}{c}\text { Number of } \\
\text { spectra }\end{array}$ & Score & \multicolumn{1}{c}{ b/y series } \\
\hline (R)ELISNASDALDKIR(Y) & 1544.8279 & 1 & 6.44 & $\mathrm{~b}_{2} / \mathrm{y}_{3}-\mathrm{y}_{6}-\mathrm{y}_{8}-\mathrm{y}_{9}-\mathrm{y}_{10}-\mathrm{y}_{12}$ \\
\hline (K)GVVDSDDLPLNVSR(E) & 1485.7544 & 4 & 16.25 & $\mathrm{~b}_{2}-\mathrm{b}_{4} / \mathrm{y}_{1}-\mathrm{y}_{2}-\mathrm{y}_{3}-\mathrm{y}_{6}-\mathrm{y}_{7}-\mathrm{y}_{8}-\mathrm{y}_{9}-\mathrm{y}_{11}-\mathrm{y}_{12}$ \\
\hline (K)SILFVPK(T) & 803.5026 & 2 & 10.34 & $\mathrm{~b}_{2}-\mathrm{b}_{3} / \mathrm{y}_{1}-\mathrm{y}_{2}-\mathrm{y}_{3}-\mathrm{y}_{4}-\mathrm{y}_{5}$ \\
\hline (R)SSGTLEMSTIK(I) & 1153.5769 & 3 & 9.93 & $\mathrm{~b}_{2} / \mathrm{y}_{2}-\mathrm{y}_{7}-\mathrm{y}_{9}$ \\
\hline (K)TLEINPR(H) & 842.473 & 1 & 5.45 & $\mathrm{~b}_{2} / \mathrm{y}_{1}-\mathrm{y}_{2}-\mathrm{y}_{3}$ \\
\hline (R)TLQAKEEDLK(L) & 1174.6314 & 1 & 4.95 & $\mathrm{y}_{1}-\mathrm{y}_{4}-\mathrm{y}_{8}$ \\
\hline (R)YITFLR(V) & 812.4665 & 2 & 5.80 & $\mathrm{~b}_{2} / \mathrm{y}_{3}-\mathrm{y}_{4}-\mathrm{y}_{5}$ \\
\hline (K)YLTFIR(G) & 812.4665 & 2 & 5.80 & $\mathrm{~b}_{2} / \mathrm{y}_{3}-\mathrm{y}_{4}-\mathrm{y}_{5}$ \\
\hline (R)YLTFLR(T) & 812.4665 & 5.80 & $\mathrm{~b}_{2} / \mathrm{y}_{3}-\mathrm{y}_{4}-\mathrm{y}_{5}$ \\
\hline
\end{tabular}




\section{SM 4 - Electrophoregrams of interspecies and inter-body-parts 2D-DIGE-comparison}
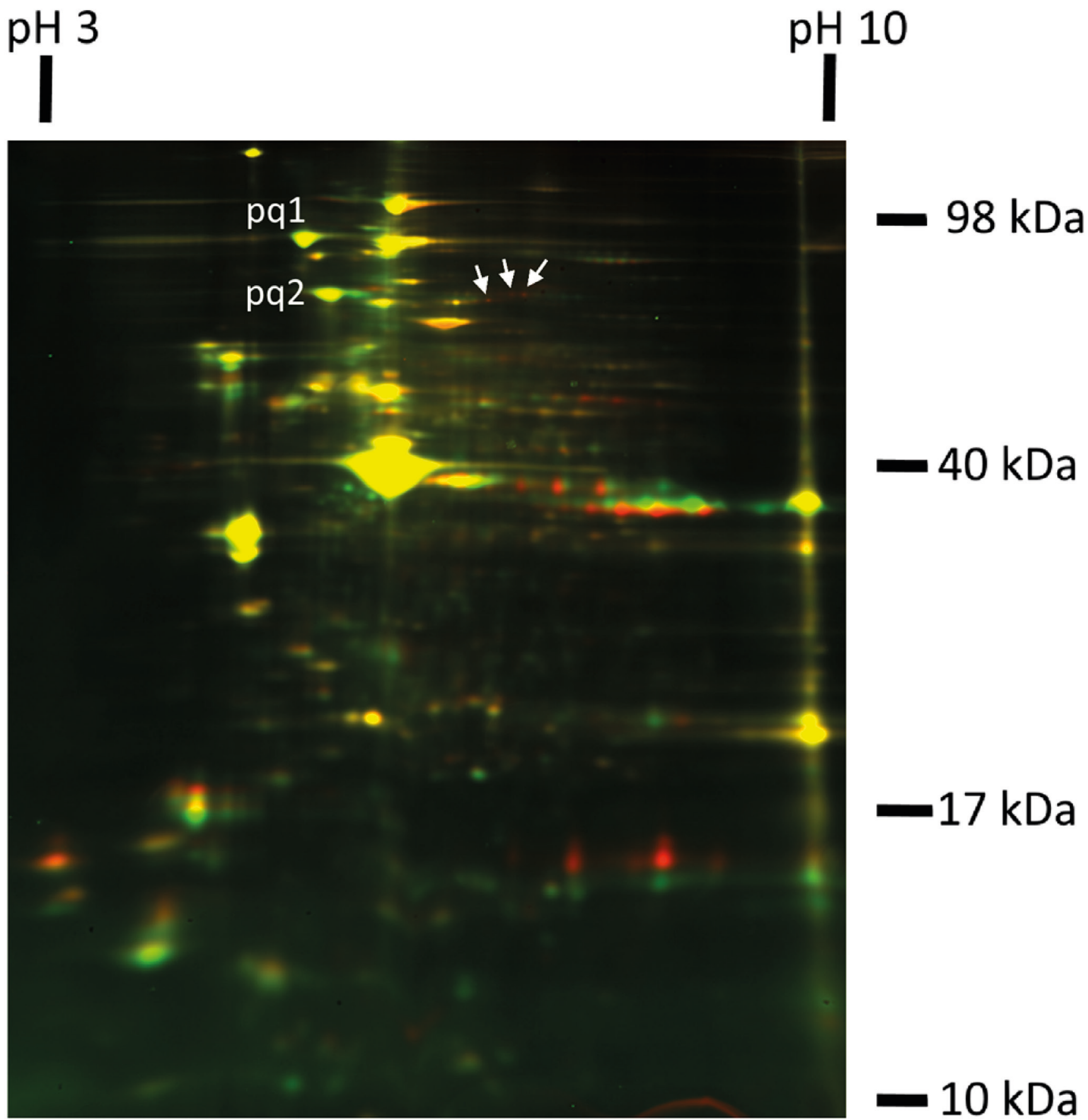

Fig. 1. 2D-DIGE of total lysates of mamilliform glands from L. obtusata (red) and L. saxatilis (green). Pq1 and pq2 are the proteins discussed in the main text with significantly higher expression level in the total lysates of mamilliform glands. Arrows show at L. obtusata-specific mamilliform gland proteins marked on Fig. 1 (a) and discussed in the main text. As mentioned in the main text, other species-specific proteins (red or green dots) were described earlier in Maltseva et al., 2016 as house-keeping proteins, expressed throughout an organism. 
$\mathrm{pH} 3$

$\mathrm{pH} 10$

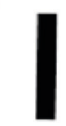

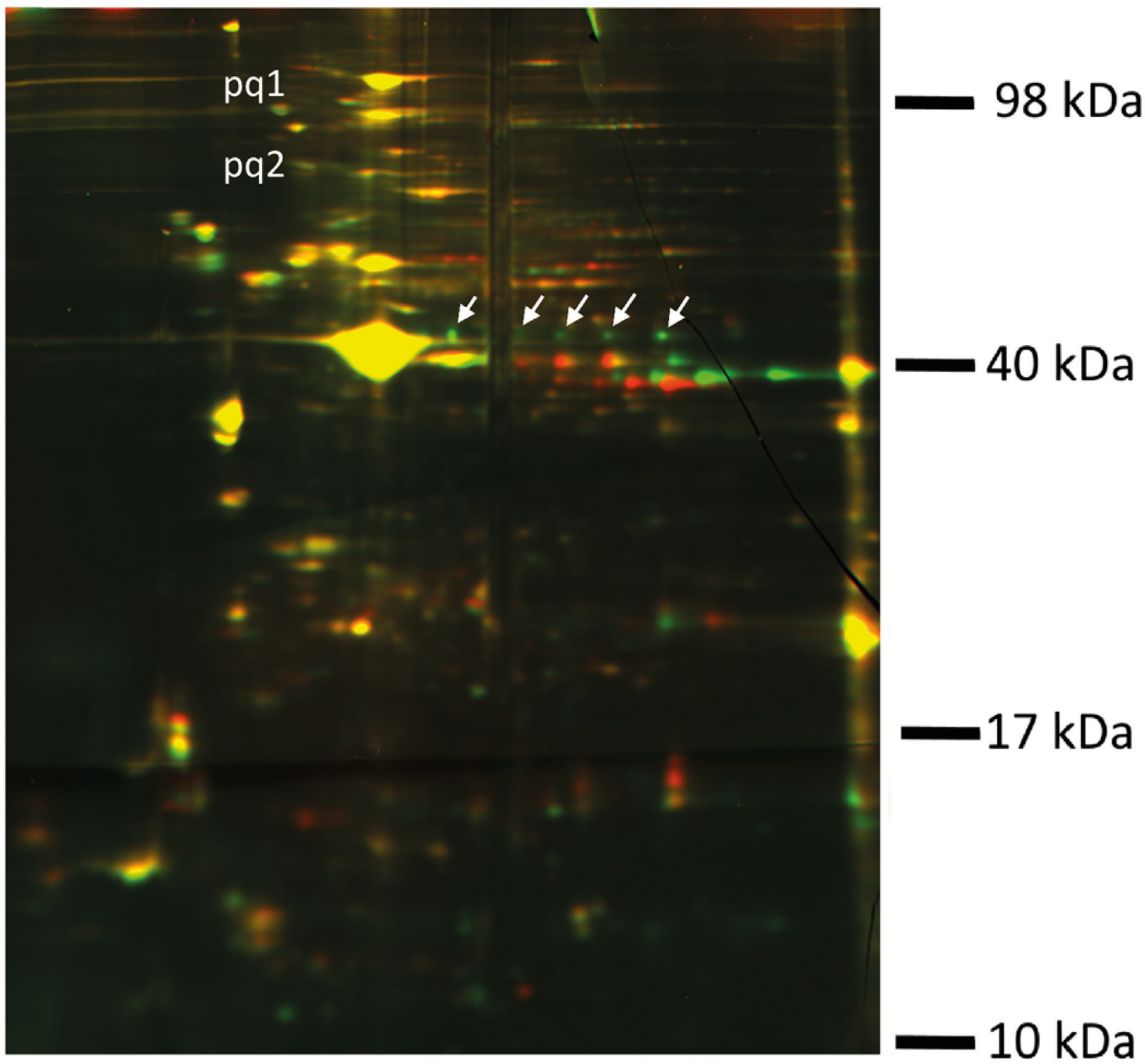

Fig. 2. 2D-DIGE of total lysates of the basal part of a penis from L. fabalis (red) and L. saxatilis (green). Pq1 and pq2 are the proteins discussed in the main text with significantly higher expression level in the total lysates of mamilliform glands. Arrows show at $L$. saxatilis/L. arcana-specific proteins from the basal part of a penis marked on Fig. 1 (a) and discussed in the main text. As mentioned in the main text, other species-specific proteins (red or green dots) were described earlier in Maltseva et al., 2016 as house-keeping proteins, expressed throughout an organism. 


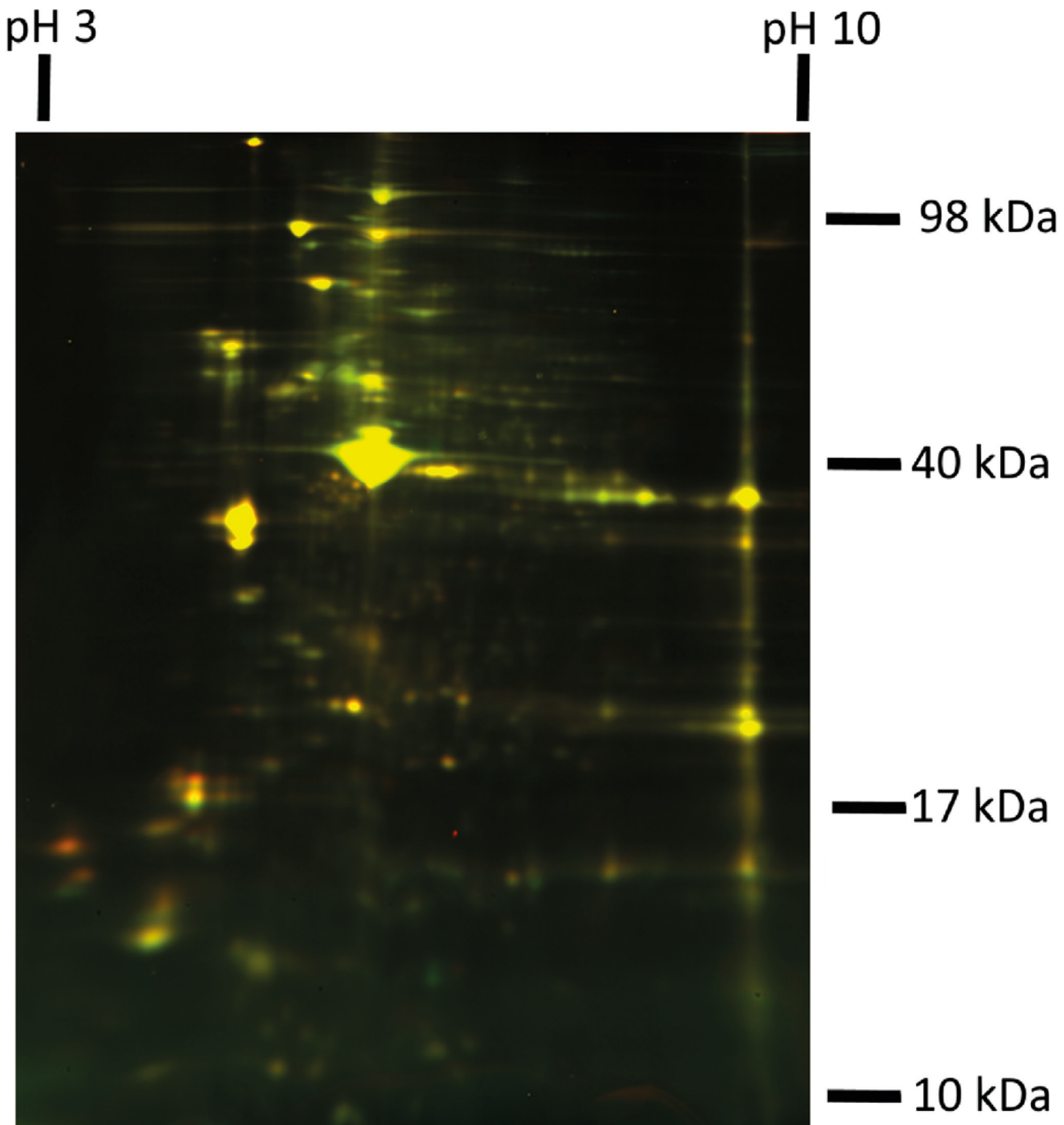

Fig. 3. 2D-DIGE of total lysates of the mamilliform glands from L. arcana (red) and L. saxatilis (green). The electrophoregram illustrates the absence of species-specific proteins in mamilliform gland proteomes in comparison between L. saxatilis and L. arcana. 


\section{SM 5 - The discussion of possible mechanisms of gametic isolation in Littorina}

For more detailed information on gametic isolation mechanisms in invertebrates see Lobov et al., 2019.

Gametic incompatibility is based on species-specific molecular interactions that prevent heterospecific fertilization. Gamete interactions in different taxa involve generally similar processes, but they often employ non-homologous molecules (the identification of their molecular functions is often a challenge). In externally fertilizing organisms gamete recognition includes only sperm and egg molecules. Apposite to them, gamete interactions in internal fertilizers (e.g. Littorina) are more complex: the basic stages of gamete recognition (chemotaxis of spermatozoa to an egg; induction of acrosome reaction and local destruction of egg envelopes by acrosomal proteins; egg and sperm membranes interaction and fusion) are combined with male-female interactions.

We suspect, that Littorina penial proteins (described in the main text) are involved indirectly to sperm-egg interactions, and through this they might be involved to reproductive isolation.

Assumption 1: if secretions of mamilliform glands or other penial glands are not entered to female copulatrix.
Possible function 1: Glueing a penis during copulation. This function of mamilliform gland secretions is aimed for keeping penis within female reproductive ducts during the copulation. It was firstly suggested in early studies and not disputed since then (Linke 1933; Bingham 1972; Reid 1989; Buckland-Nicks \& Worthen, 1992).

Possible function 2: Female physiology modification. Numerous proteins transferred during copulation have strong effects on a female behavior and physiology (e.g. Avila et al., 2011); proteins of penial glands secretions might belong to this functional groups bringing some signal for a female organism.

Assumption 2: secretions of penial glands are mixed with sperm during copulation. In this case, possible functions of penial gland proteins are rather similar to proteins of seminal fluid, which are well studied in insects (e.g. Avila et al., 2011, 2016).

Possible function 3: sperm conditioning. In internally fertilizing organisms the state of spermatozoa is regulated by the components of seminal fluid and female reproductive tracts. According to this, proteins of penial gland being mixed with sperm can influence Littorina sperm state.

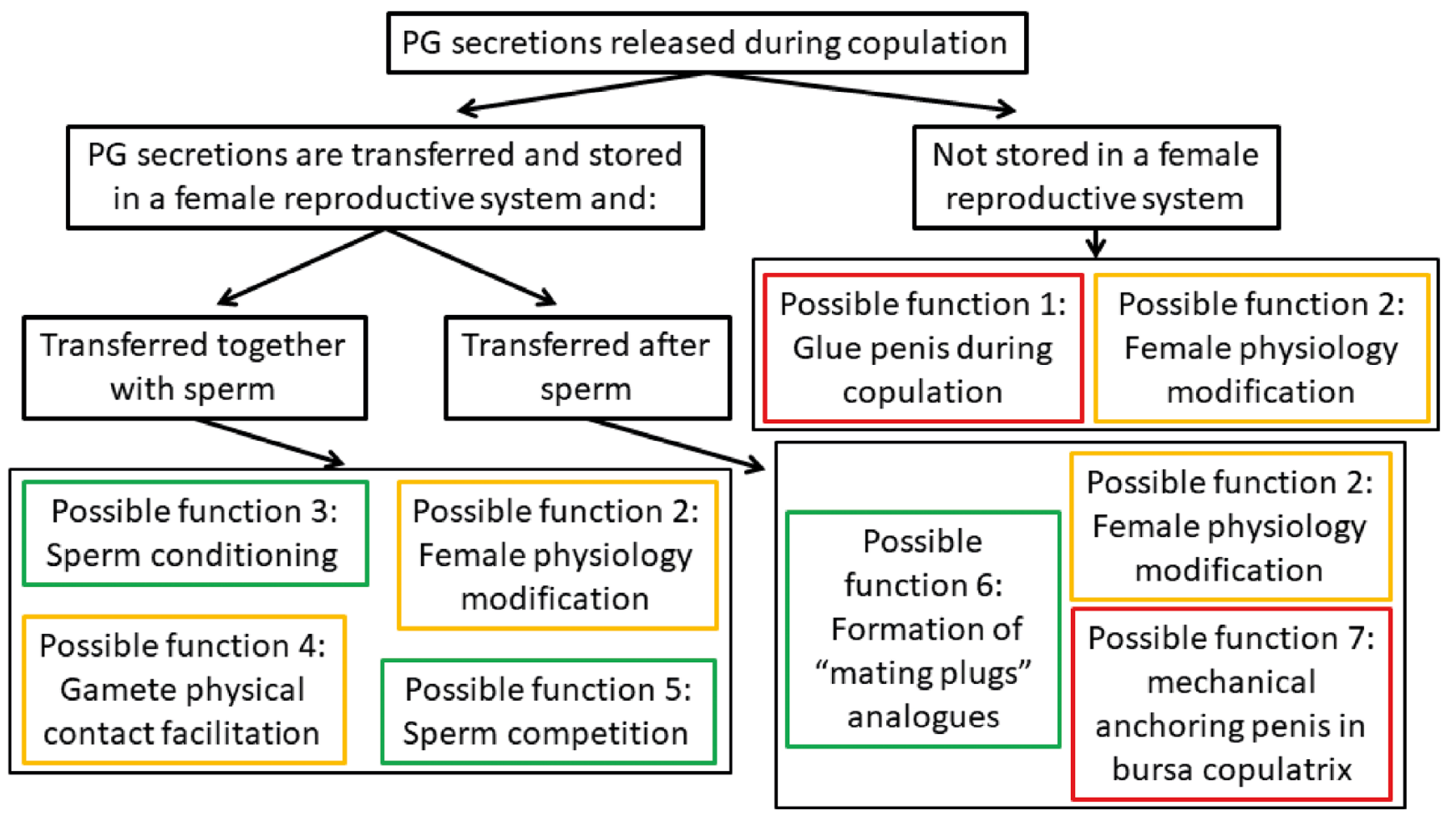

Fig. 1. Possible functions of proteins, secreted by penial glans (PG). In black frames there are presumable protein functions; in red frames possible functions with no relation to reproductive isolation; in yellow frames - possible functions potentially connected with reproductive isolation; in green frames - possible functions directly related to reproductive isolation. 
Possible function 4: gamete physical contact facilitation. Some proteins of seminal fluid are able to form filaments and complex three-dimensional structures, which mechanically facilitate fertilization. Similarly, PG proteins may be recruited to such complexes.

Possible function 5: sperm competition. In a case of polyandry, female mates with many males, and their sperm compete for an egg fertilization., Such competition is often regulated by seminal fluid proteins. Noteworthy, the results on Littorina sitkana (the Neritrema subgenus) showed no negative effect of the mamilliform gland secretions on a competitor's sperm (BucklandNicks \& Worthen, 1992). Yet, this function cannot be excluded, as possible action of mamilliform gland secretions may occur, only when they are mixed with some female compounds or proteins of other penial glands.
Assumption 3: secretion of mamilliform glands or other penial glands is delivered to a female, but only after sperm.

Possible function 6: formation of "mating plugs" analogues. The production of physical barriers that prevent females remating is quite common in insects and other taxonomical groups, such as nematodes, arachnids, amphibians, mammals and cephalopods (Saad, 2018; Sutter, 2016). Nevertheless, it is rather unusual in gastropods. Moreover, the Littorina periwinkles are well studied at the morphological, ultrastructural, anatomical and physiological levels, and there are no signs of mating plugs. Thus, mating plugs formation is very unlikely scenario in the Littorina case.

Possible function 7: mechanical anchoring penis within a bursa copulatrix. Normal copulation in Littorinas takes 30-40 minutes, and the existence of special penis anchoring mechanisms is rather probable. 